\title{
Juvenile Delinquency: Its Causes and Effects
}

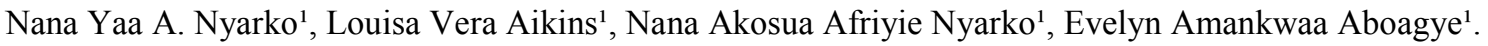 \\ Nana Yaa A. Nyarko ${ }^{1 *}$ \\ Department of Family and Consumer Sciences, University of Ghana \\ PO box 91, Legon, Accra, Ghana
}

\begin{abstract}
The aim of the study was to find out the circumstances that led inmates of two correctional facilities for young offenders into behaviours considered criminal and the effect it has had on them and the society they lived in. The study hypothesized that; peer association and family situation will influence delinquency and that delinquency did not have a significant effect on the future (schooling) of the juveniles affected. Fifty-seven (57) inmates of two Junior Correctional Centres in Accra were conveniently selected to respond to a structured questionnaire. Juveniles attributed the causes of their delinquent behaviours to their own initiatives, family situations, spiritual influences and peer association. Peer pressure was found to influence adolescent behaviour formation. Implications of juveniles' incarceration and parental role in guiding adolescent children are discussed.
\end{abstract}

Keywords: delinquency, juvenile, causes, peer association.

DOI: $10.7176 / \mathrm{JLPG} / 88-24$

Publication date: August $31^{\text {st }} 2019$

\section{Introduction}

Children and youths have engaged in offending behaviours due to various reasons. Some of these behaviours have been attributed to experimenting as well as crisis associated with 'normal' adolescent growth and development. Some of these acts have been extreme and unlawful resulting in dire consequences for their future and the wellbeing of society. Offences and other infringements of the law perpetrated by children below the age of adulthood is termed juvenile delinquency (Ferdousi 2013). Juvenile delinquency has been on ascendency at alarming rate in both developed and developing nations (Ferdousi 2013). In Ghana juvenile delinquency is especially frequent in the major urban cities of Accra and Kumasi. Most of these delinquents are repeated offenders who tend to master criminal acts in prisons rather than being reformed.

Traditional patterns of guiding behaviour, relationships and social relations that ensure a smooth process of socialization are failing. Varying lifestyles, limited opportunities for young adults to become independent, poverty, unemployment among the youth, a decline in authority of local communities, disintegration of the family, ineffective educational system are some of the pressures that the youth has to deal with. (World Youth Report 2003). Poor socioeconomic background, emotional strains, negative peer influence, parental absence and negative community elements all in a way influence young adult to engage in behaviours that affect others (Simoes et al. 2008; Hunte 2006).

Every society has laid down rules to guide behaviour and bring about order, but deviance cannot be avoided. With our traditional patterns of guiding behaviour, relationships and socialization collapsing, young people are therefore at risk of becoming delinquents (World Youth Report 2003).

According to the Beijing Rule of the United Nations Standard Minimum Rules for the administration of Juvenile Justice, a juvenile is defined as 'a child or young person who under the respective legal system, maybe dealt with for an offence in a manner which is different from an adult' (Godswill 2013). In Ghana the Juvenile Justice Act, 2003 (Act 653) defines a juvenile as 'a person under 18 years who is in conflict with the law' (pp 4). Criminologists explain that juvenile delinquency encompasses all public wrongs committed by young people between the ages of 12 and 20. It is the habitual committing of criminal acts or offences by a young person especially one below the age of 18 at which ordinary criminal prosecution is possible. Over the years the Ghanaian society has seen a great change in the behaviour of the youth. There is a change from the usual bad boys and girls who flouted rules in school to children who now engage in adult crimes (Boye-Doe 2008). Examples of such crimes include; cyber fraud, robbery, car snatching, rape and other sexual offences.

Setyorini et al. (2014) document that young people who become delinquents often live in difficult circumstances. Delinquency was often a result of the home, family, neighbourhood, peers and other variables that influences behaviour formation. Some of the difficult situations include - poverty, breakdown of the family, housing and other necessities, parental alcoholism, overcrowding, abusive conditions in the home, death of parent during armed conflicts, becoming orphans and without any means of subsistence (Setyorini et al. 2014 ; Omboto et al. 2013 ; Thornberry \& Krohn 2000; Thornberry et al. 2004; \& Weinberg 1964). These put children at risk of becoming delinquent. Every country's rich source of human resource lies in the youth. Thus policy makers must consider the welfare of its youthful population knowing that some juveniles do not engage in criminal activities intentionally (Ashiabor 2014). 


\subsection{Theoretical Perspective to Juvenile Delinquency}

Delinquency and crime have been explained from different perspectives by several schools of thought. Many theories about the causation of juvenile delinquency have emerged over time.

Early theorist believed that attitudes' relating to delinquency among children was as a result of naturalism and demonology (Martin 2005). Human criminality was a consequence of wrongdoer's inappropriate connection with the supernatural powers (demonology) and or nature (naturalism) based influences. Naturalism eliminates individual responsibility for one's lack of responsible self-control i.e. human behaviour is derived from the forces of nature hence we are to be adept at understanding how the forces work and develop the ability to interpret them and adapt. Demonology on the other hand explain offenses as essentially spiritual sins or crimes against the natural order and punishments were divinely sanctioned. In the Medieval and renaissance era all offenses committed were against God and the Roman Catholic Church. It was believed that offenses were manifestations of conflicts between demonic creatures and goodness as well as chaotic and order. Exorcism was the form of punishment that was used to drive out demons from the 'possessed' (Martin 2005).

1.1.1 Psychological school

The psychology school of thought bases behaviours on personality and childhood dysfunctions. It is an interaction of stimulus - responses, rewards - punishments, personalities (Id, Ego and Super Ego). In this paper, the psychanalytic and the classical conditioning theories will be discussed. Freud highlights 3 fundamental components that influence behaviour- Id, Ego and Super ego. A healthy development of these parts occurs early in life. Hence traumatizing events during childhood can become catalysts for delinquency and criminality. He explains that, if the super ego (the morality and conscience) does not develop properly this results in an unchecked Id and may lead to a child imbibing deviance as an acceptable behaviour. The ripple effect is that if such behaviour is illegal, it forces the society to define the individual as delinquent or a criminal. Hence delinquency is a result of conflict between the id, ego and super ego (Martin 2005b). Freud proposed 5 stages of personality development; Oral stage (satisfaction is centered around the mouth), Anal stage (toilet training), Phallic stage (fixation-sexual conquests and the exploration of the genitals), Latent stage (dormancy of the sexual instincts) and Genital stage (learning to express sexuality appropriately in line with societal norms) (Benveniste 2015) .

Therefore, for example; if an individual gets fixated at the phallic stage and is not 'weaned' he/she may become sexually deviant and engage in unlawful sexual practices such as prostitution or rape.

Conditioning theory (learning by experience); our environment informs our experiences which informs our behaviour. Ivan Pavlov is famous for his behavioural experiment with his dog. His experiment yielded Stimulusresponse and reward- punishment. Using Pavlov's ideas to explain delinquency, criminals are conditioned to continue their behaviour as a result of the stimuli in the environment and therefore continue to behave defiantly (Moore 2011).

1.1.2 Sociological school

Differential Association theory- This theory identifies processes by which delinquent behaviours are learnt. For example, the process of learning criminal/delinquent behaviour is by association with criminal patterns and all other mechanisms that may be involved. Secondly delinquent behaviours are learnt through communication/ interactions with other people (Martin 2005). Sustained contact with individuals who harbour the norms of delinquency (Wood \& Alleyne 2010) is disastrous. For as long as young persons interact with law breakers, they will learn that behaviour (Osei Boakye 2012). This perspective has implications on the influence of the family, peers and the mass media in shaping of behaviours of young people. Learning is done through motivation, imitation and association. As differential association simply means 'bad company corrupts good manner' the role of peer relationships in determining deviancy is highlighted (Bosiakoh \& Andoh 2010)

General theory of crime- Delinquents have been known to have a common behavioural pattern which finds expression in their self-control- the degree to which an individual is 'vulnerable to the temptations of the moment' (Gottfredson \& Hirschi 1990, p.87). Delinquents often have low self-control which is usually a result of the early stages of their development (Longshore et al. 2004). Childhood aggression (annoying others or bullying) and or developmental pathways such as authority avoidance (truancy, running away, staying out late, disobedience), physical fighting, burglary, prostitution, aggravated assault, forcible rape among others (Levitt 1996) are a result of low self-esteem.

Exploring causes of delinquency unveils the interactions between family relationships, mass communication and peer influence (Marcos et al. 1986, Ingram et al. 2007). The principles of social learning discourses family relationships and juveniles' involvement with deviant peer groups, which happens to be a major agent of socialization of children. When families lack effective parental supervision of children's activities, it increases the probability of the child's contact with deviant peers (Ingram et al. 2007). In adolescence, the desire for an identity consumes them and cause them to begin to separate themselves from their families and try out different roles and situations to figure out who they are and where they fit into the world. They spend more time with their friends and less time with their families. Though this is a normal healthy stage of development, 
the growing distance between parents and their children and the increasing importance of friends can be a source of conflict and anger within the family. The desire to feel accepted and to fit in is one of the strongest forces in adolescents; this can lead teens to do things that they know are wrong, dangerous, or risky (Adesoji 2010). High crime rates involving children can only signify a breakdown of the family structure. Regrettably, some parents are too busy working for money for sustenance and have no time to supervise children and bring them up in the right way (Boye-Doe 2008). Unable to have their parents meet their material needs, some children turn to all sorts of activities, many of which eventually lead to delinquent acts (Bosiakoh \& Andoh 2010). Delinquency therefore is a result of economic and family relational problems.

On another hand, the society's emphasis on materialism as a sign of success is a contributing factor. Social structures exert pressure on individuals, more so in the area of the aspirations of its members (Farnworth \& Leiber 2007; Agnew et al. 2006). Merton's Strain theory is key, according to him deviant behaviour "may be regarded sociologically as a symptom of dissociation between culturally prescribed aspirations and socially structured avenues for realizing these aspirations" (Merton 1968, pp.202). Thus, in Ghana, citizens are pressured to aspire for wealth, political power and sometimes high educational achievement in the face of scarce resources and opportunities lending support to the saying that "the end justifies the means".

Often, juveniles are unaware of the outcomes of their crimes when caught and only become aware when they have to come to terms with incarceration and its aftermath. Juveniles stand the risk of losing their freedom and rights whilst being incarcerated. Education which is basic for all children (Children's Act 1998) could be lost due to imprisonment. They may tend to lose interest in schooling altogether. Those who want to, do not get the chance and upon their release, find themselves behind their age/classmates.

Another worrying issue is that their placement in residential centres brings them in contact with the other delinquents who maybe sophisticated and or influential. This could make room for recidivism which in turn affects the adolescent's academic and career options (Mallett et al. 2013).

Delinquency affects the family in many ways such as family relationships, support and stigmatization and the general socialization to achieve societal goals.

\subsection{Problem Statement}

An increase in juvenile offence threatens the country with an increase in adult offenders. The causes and effects of juvenile delinquency have often been documented with parents and officials of correctional facilities as informants. The alarming rate of juvenile delinquency drives the need to investigate from juveniles, the causes and effects of such behaviours. In this study researchers sought to find out from the juveniles themselves the circumstances that led them into delinquency and discover how such behaviours affected them, their families and the society they lived in.

The Objectives of the study are as follows to:

1. Find out the causes of juvenile delinquency from inmates of correctional facilities in Accra Ghana.

2. Assess the effects of incarceration on delinquent juveniles and their families.

To this end the following hypotheses were stated:

$\mathrm{H}_{1}$ : Family situation has no significant effect on juvenile delinquency.

$\mathrm{HO}_{2}$ : Peer association has no significant effect on juvenile delinquency.

$\mathrm{H}_{3}$ : Juvenile delinquency has no significant effect on the schooling of the juvenile.

\section{Methodology}

\subsection{Participants}

The study involved inmates at two Correctional facilities in the Greater Accra Region. Participants were 57 made up of, 50 Boys and 7 females. A structured questionnaire was developed and administered to collect data on respondents personal and family background information, causation of their delinquent behaviour, effects of their behaviour and information about factors that influenced their behaviour. Permission was granted the researchers since the study was of minimal risk to the participants (minors), and officer/ supervisor was always present during data collection. Languages used for the interview were English (inmates who demonstrated a good understanding of English language could answer the questionnaire themselves) and Twi (to augment the data collection process). The Statistical Package for Social Sciences (SPSS version 20) software was used to generate frequencies and percentages.

\section{Results and Discussion}

\subsection{Demographic data on respondents}

Many inmates constituting $47 \%$ had at least basic education up to Junior high school level. In terms of the living arrangements of respondents prior to incarceration, 17 and 18 of the delinquents lived with only one of their parents (because the other parent was either deceased or divorced) and other relatives/friends respectively. This may account for their exposure with bad company and hence their committing of crimes if high supervision is 
not given. However, 22 respondents lived with both parents but still found themselves committing crimes. Various reasons were attributed to their being there such as neglect or a large family size with little or no income. Thirty-five (35) of the respondents lived in a family of 6-10 individuals of which such a family is large hence a completion for resources and attention may be difficult to get and hence may be a reason to find them committing crimes to survive.

Table 1. Demographic information of respondents

\begin{tabular}{|l|l|l|}
\hline Level & Frequency & Percentage \% \\
\hline Educational Level & & \\
\hline Primary & 7 & 12.3 \\
\hline Junior High School & 27 & 47.4 \\
\hline Senior High School & 10 & 17.5 \\
\hline Others & 1 & 1.8 \\
\hline No formal education & 12 & 21.0 \\
\hline Living Arrangements Type & & \\
\hline Single Parent & 17 & 29.8 \\
\hline Both Parents & 22 & 38.6 \\
\hline Other relatives & 18 & 31.6 \\
\hline Household Size & & \\
\hline $1-5$ & 13 & 22.8 \\
\hline 6-10 & 35 & 61.4 \\
\hline Above 10 & 9 & 15.8 \\
\hline
\end{tabular}

3.2 Crimes Committed by Delinquents

Petty theft (stealing) was the highest form of crime committed by respondents (table 2). The least crimes were robbery, murder, prostitution, internet fraud and causing unlawful harm.

Table 2. Crimes committed by juveniles

\begin{tabular}{|l|l|l|l|}
\hline Offence & Male & Female & Total Freq. \\
\hline Assault & 2 & - & 2 \\
\hline Stealing & 37 & 3 & 40 \\
\hline Manslaughter & 2 & - & 2 \\
\hline Defilement & 6 & - & 6 \\
\hline Drug possession & -1 & 1 & 1 \\
\hline Robbery & 1 & - & 1 \\
\hline Internet fraud & & & 1 \\
\hline Murder & -1 & 1 \\
\hline Prostitution & - & 1 & 1 \\
\hline Causing unlawful harm & & 1 & 1 \\
\hline
\end{tabular}

\subsection{Causes of Respondents' Delinquency}

The various factors that respondents gave as having influenced their behaviour include family situation, peer pressure and others. Of the $84 \%$ who selected only one cause, $45.6 \%$ and $38.6 \%$ attributed the causes of their behaviours to their family situations and their friends respectively (table 3). These were not different from findings of Simones et al. (2008) and Hunte (2006). 
Table 3. Causes respondents attributed to their delinquent behaviours

\begin{tabular}{|l|l|l|}
\hline Factors & Frequency & Percentage \% \\
\hline Family Situation & & \\
\hline Financial problems & 7 & 12.3 \\
\hline Parental neglect & 3 & 5.3 \\
\hline Peer Association & & \\
\hline Friends & 22 & 38.6 \\
\hline Other Factors & & \\
\hline Societal Influence & 2 & 3.5 \\
\hline Spiritual & 1 & 1.7 \\
\hline Own initiative & 12 & 21.1 \\
\hline Self defence & 1 & 1.7 \\
\hline Multiple responses & & \\
\hline Friends and financial problems & 7 & 12.3 \\
\hline Unknown & 2 & 3.5 \\
\hline
\end{tabular}

\subsection{Effects of Juvenile Delinquency}

The effects of juvenile Delinquency on the inmates are classified into self, education and family relationships (table 3). Approximately 76\% (43) of respondents reported that the offences they committed had affected them.

Table 4. Effects of juvenile delinquency on respondents'

\begin{tabular}{|l|l|}
\hline POSITIVE & NEGATIVE \\
\hline Self & \\
\hline Learn to control behaviour & Stigmatization \\
\hline Learnt a trade & Withdrawn from home \\
\hline Learnt how to live and cope with others & Learnt bad behaviours from the correctional home \\
\hline Education & Poor feeding \\
\hline Can continue schooling & \\
\hline Learning a trade & Disrupted schooling \\
\hline Family relationships & \\
\hline Has family support & \\
\hline & Lack of trust \\
\hline & Stigma attached to family \\
\hline
\end{tabular}

Their responses have been grouped into positive and negative effects. Positively, being in the various correctional homes has helped them control their behaviour and as well learn how to cope with others. The opportunities provided in the home allow them to learn some form of vocational skills such as hairdressing (girls) and vulcanizing (boys). The negative effects included the stigmatization they suffer for being criminals etc.

For the $37 \%$ (21) of respondents who mentioned that their behaviour influenced their education, their responses were grouped into positive and negative effects. The correctional centres provided education for its inmates. The Boys correctional centre had both formal education (JHS) and vocational training and the girls only had vocational training school but however those who had their education disrupted were those who had completed junior high and or senior high schools. This was because the facility was not in the position to offer tertiary education for inmates.

In terms of the effect of their behaviour on their family relationships $56.1 \%$ (32) responded Yes and their responses were grouped into positive and negative effects.

3.4.1 Hypotheses Testing

Three (3) hypotheses were tested in the study. The chi-square was used for the purpose. The null hypothesis (Ho) was tested in each case at 0.05 level of significance.

Hypothesis one

Ho : Family Situations have no significant effect on juvenile delinquency

Table 5. Chi-square analysis for hypothesis one

\begin{tabular}{|l|l|l|}
\hline Value & Df & Asymt.sign \\
\hline $7.737 \mathrm{a}$ & 1 & 0.005 \\
\hline $14.000 \mathrm{~b}$ & 1 & 0.000 \\
\hline
\end{tabular}

The $\mathrm{P}$ value 0.005 was obtained after testing the hypothesis. This value is less than the level of significance (0.05). As such we reject the null hypothesis. Family situations significantly affects juvenile delinquency. 
Hypothesis two

Ho : Peer association has no significant effect on juvenile delinquency.

Table 6. Chi-square analysis for hypothesis two

\begin{tabular}{|l|l|l|}
\hline Value & Df & Asymt.sign \\
\hline $6.333 \mathrm{a}$ & 1 & 0.0012 \\
\hline $14.000 \mathrm{~b}$ & 1 & 0.000 \\
\hline
\end{tabular}

The $\mathrm{P}$ value 0.00 was obtained after testing the hypothesis. This value is less than the level of significance $(0.05)$. As such we reject the null hypothesis.

Hypothesis three

Ho : Juvenile delinquency has no significant effect on the schooling of the delinquent.

Table 7. Chi-square analysis for hypothesis three

\begin{tabular}{|l|l|l|}
\hline Value & Df & Asymt.sign \\
\hline $39.263 \mathrm{a}$ & 2 & 0.008 \\
\hline $14.000 \mathrm{~b}$ & 1 & 0.000 \\
\hline
\end{tabular}

The $\mathrm{P}$ value 0.008 was obtained after testing the hypothesis. This value is less than the level of significance (0.05). As such we reject the null hypothesis.

\subsection{Conclusion}

From this study, researchers can conclude that family situation influences children becoming delinquents. Peers play a major role in behaviour formation especially during the adolescent stage. The juveniles being arrested disrupted the education of some and brought about some negative changes in their behaviour, physical and social wellbeing. Whiles some families became more supportive of their wards after incarceration, others neglected and stigmatised them making it difficult for them to return after having served their term. The study has implications on parenting education in terms of child rearing practices and the integration of delinquent children upon their release.

\section{References}

Agnew, R. et al. (2006) 'Strain, Personality Traits, and Delinquency: Extending General Strain Theory', Criminology, 40(1), pp. 43-72. doi: 10.1111/j.1745-9125.2002.tb00949.x.

Ashiabor, D. T. (2014) The Impact of the Swedru Junior Boys Correctional Centre on the Reformation of Juvenile Offenders. University of Ghana.

Benveniste, D. (2015) Sigmund Freud and Libido Development. Available at: http://www.benvenistephd.com/.

Boye-Doe, K. (2008) 'Delinquents in Modern Ghana', Ghana Web. Available at: https://www.ghanaweb.com/GhanaHomePage/features/Delinquencies-in-Modern-Ghana-137459\#.

Farnworth, M. and Leiber, M. J. (2007) 'Strain Theory Revisited.pdf', American Sociological Review, 54(2), pp. 263-274.

Ferdousi, N. (2013) 'Juvenile Justice for the Best Interest of the Children in Bangladesh: A Legal Analysis', Journal of Law, Policy and Globalization, 18, pp. 22-32.

Godswill, J. (2013) 'Assessment of the administration and practice of juvenile justice system in Abuja, Nigeria', Mediterranean Journal of Social Sciences, 4(1), pp. 331-338. doi: 10.5901/mjss.2013.v4n1p331.

Hunte, M. (2006) 'A Qualitative Study of Delinquency and Achievement Among Low Income Youth in Trinidad', in A Paper presented at SALISES 7th Annual Conference. University of West Indies, Cave Hill, Barbados., pp. 1-26.

Mallett, C. A. et al. (2013) 'Factors related to recidivism for youthful offenders', Criminal Justice Studies, 26(1), pp. 84-98. doi: 10.1080/1478601X.2012.705539.

Martin (2005a) 'Juvenile Delinquency: Theories of Causation', in UNDERSTANDING JUVENILE JUSTICE PROCESS AND SYSTEMS, pp. 61-93. doi: 10.4135/9781412952484.n363.

Martin (2005b) 'Understanding Juvenile Justice Process and Systems', in Juvenile, pp. 405-410. doi: 10.4135/9781412952484.n363.

Merton, R. K. (1968) Social Theory and Social Structure. New York:, New York. The Free Press.

Moore, M. (2011) 'Psychological theories of crime and delinquency', Journal of Human Behavior in the Social Environment, 21(3), pp. 226-239. doi: 10.1080/10911359.2011.564552.

Omboto, J. O. et al. (2013) 'Factors Influencing Youth Crime and Juvenile Delinquency', International Journal of Research in Social Sciences, 1(2), pp. 18-21.

Osei Boakye, A. O. (2012) Juvenile delinquency in Ghana: a qualitative study of the lived experiences of young offenders in Accra. Norwegian University of Science and Tecnology.

Setyorini, E. H. et al. (2014) 'The Formulation Policy for the Regulation on the Implementation of Diversion which Reflects the Principles of Protection and Welfare for Children Conflicting against the Law in the Future', Journal of Law, Policy and Globalization, 32, pp. 73-82. 
Simoes, C., Matos, M. G. and Batista-Foguet, J. M. (2008) 'Juvenile Delinquency: Analysis of Risk and Protective Factors Using Quantitative and Qualitative Methods', Cognition, Brain, Behavior. An Interdisciplinary Journal, 12(4), pp. 389-408.

Thornberry, T. and Krohn, M. (2000) 'The self-report method for measuring delinquency and crime', Criminal justice, 4(1), pp. 33-83.

World Youth Report (2003) Juvenile Delinquency. doi: 10.1515/9783110289039.734.

Weinberg, S.K. (1964). Juvenile Delinquency in Ghana: A Comparative Analysis of Delinquents and NonDelinquents. Journal of Criminal Law and Criminology, 55(4), 471-481. 